\title{
IN SEARCH OF TRANSFORMATIVE MOMENTS: BLENDING COMMUNITY BUILDING PURSUITS INTO LIFELONG LEARNING EXPERIENCES
}

\author{
MIKULAS PSTROSS \\ Osher Lifelong Learning Institute at ASU \\ Arizona State University, 411 N. Central Avenue, Phoenix, AZ, USA \\ E-mail address: Mikulas.Pstross@asu.edu \\ Craig A. TAlmage \\ Entrepreneurial Studies \\ Hobart and William Smith Colleges, 300 Pulteney Street, Geneva, NY, USA \\ E-mail address: talmage@hws.edu \\ C. BJØRN PETERSON \\ Partnership for Community Development \\ Arizona State University, 411 N. Central Avenue, Phoenix, AZ, USA \\ E-mail address: C.Bjorn.Peterson@asu.edu \\ RICHARD C. KNOPF
}

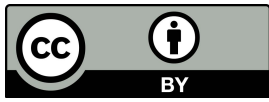

Osher Lifelong Learning Institute at ASU, Partnership for Community Development Arizona State University, 411 N. Central Avenue, Phoenix, AZ, USA

E-mail address: Richard.Knopf@asu.edu

\begin{abstract}
This article presents an exploration of the relationship between community building and lifelong learning. Using a reflective style, the authors propose that the fusion of community building principles with lifelong learning practice can positively transform educational practice. Seven positive pursuits are highlighted regarding their potential to assist the implementation of community building into lifelong learning programs: (1) asset-based thinking; (2) critical reflection; (3) systems thinking; (4) cognitive vibrancy, (5) inclusiveness; (6) creative expression; and, (7) purpose in life. These pursuits draw upon the power of the community development field to bring about more positive transformative moments for individuals and communities participating in lifelong learning programs. The metaphor of bread making is used to illustrate how such transformative moments occur and why they are meaningful to individuals pursuing lifelong learning.
\end{abstract}

Key words: lifelong learning, community building, older adults, transformative learning, positive pursuits 


\section{INTRODUCTION}

Human learning does not take place in a relational vacuum. From birth, those who surround the human life affect the paths set before it and affect how the diverse pathways of life are navigated. Learning and community are inseparable; as the adage goes, "it takes a village to raise a child." Community thus remains significant in our lifelong endeavors to learn. But, what pursuits are necessary to intentionally build a community in and through educational programs that support lifelong learning and therefore escalate the lifelong learning experience?

The purpose of this article is to engage researchers and practitioners (e.g., community workers, university personnel, and lifelong learning programmers) in a discussion about positive practices that constitute appealing and engaging learning environments. The notion of lifelong learning is understood as learning that is sought by individuals, but also may be part of educational institutions, such as a university in the exemplar that we are about to present (Jarvis 2004). Fehren (2010) proposed the universities can act as intermediaries in community development of which we propose lifelong learning plays an important role.

In order to be successful, Shaw and Crowther (2014) noted that the relationship between lifelong learning and community development needs to be renegotiated, and such renegotiation requires rooting in theory and practice. Two discourses taken from Schugurensky (2007) frame our understanding of lifelong learning: the liberal humanist approach (which emphasizes self-actualization of learners), and the social movement approach (which values democratic community involvement and designates value to societal changes). In their intent, these discourses relate to Bhattacharyya's (1995) notion that the field of community development is to be focused on developing agency and solidarity. We present our claims drawing on historical traditions of theory and practice that comingle lifelong learning and community development. We claim that the infusion of community building principles into lifelong learning practice helps bring about what we call transformative moments to learners. Our notion of transformative moments was inspired by Mary Lou Kownacki's (2002) book, The Nonviolent Moment, which offers a series of contemplative stories and encourages readers to reflect on their roles in the struggle for justice. We see transformative moments as times during which individuals, together, experience a sense of community, connection, and empowerment that motivate them to reflect on their roles in their own communities as learners, citizens, and leaders.

In its focus on transformations in learning, our article alludes to the theory of transformative learning (for a review, see Taylor, 2007) which includes as one of its tenets the notion that "...[1]earning is understood as the process of using a prior interpretation to construe a new or revised interpretation of the meaning of one's experience in order to guide future action" (Mezirow, 1996, p. 162). Though not fully building on transformative learning theory, we allude to some of its tenets. 


\section{COMMUNITY BUILDING PRINCIPLES AND LIFELONG LEARNING PRACTICE ARE INTERTWINED}

We examine the relationship between community building principles and lifelong learning practice from the perspective of a lifelong learning praxis a theory-building cycle of action and reflection (Freire, 2000). Our argument is that community building and lifelong learning are intertwined through transformative moments in the lives of individuals and their communities. Programs that encourage lifelong learning should and can be guided by a vision to bring about positive individual and community transformations. These transformations reflect the capacity to produce, through lifelong learning, a more just and peaceful society and a caring and collaborative world that values learning for learning's sake. In other words, transformative moments can better our communities and amplify the power of lifelong learning simultaneously. In the spirit of Gruidl and Hustedde (2003) work to provide account of how the creation of learning communities enhances community development effort; we explore the reverse: "What pursuits are necessary for introducing community building into lifelong learning practice?"

\section{OUR REFLECTIVE PROCESS}

In answering the question, all four of us authors drew from experiences from working in two centers at Arizona State University (ASU): the Partnership for Community Development (PCD) and the Osher Lifelong Learning Institute at ASU (OLLI at ASU).

At the heart of the PCD's work lies community building. The PCD works with communities to improve quality of life in communities and to enhance the participation of community members in the places where they live and work. The PCD engages ASU faculty and students in community visioning, asset mapping, action planning, facilitation, and community evaluation. It also provides a space for reflection about the intersection of community development theory and practice. The PCD focuses on community building from a diversity of perspectives, among which service learning, inclusiveness, and theoretical reflection play key parts (Partnership for Community Development, n.d.).

OLLI at ASU's mission is to encourage lifelong learning in the third age. OLLI at ASU connects adults 50 years-of-age and older in the Phoenix metropolitan area to ASU through campus-based learning opportunities, civic engagement initiatives, and short courses and lectures featuring diverse topics and issues (Osher Lifelong Learning Institute at ASU, n.d.). Through memberships in the institute, older adults become embedded in the university life at ASU, access opportunities for community engagement (e.g., volunteering) and take on leadership roles in their community. They are able to discover new ways to apply past experiences, expertise, and gifts to community service. 
Our experiences from designing the programming for both the PCD and OLLI at ASU led us to explore the relationship between community building and lifelong learning. Together we examined answers to the following two questions: (1) What do we do when we are at our best in the PCD; and, (2) What do we do when we are at our best in OLLI at ASU? We came up with a list of 24 items that assemble the multiple dimensions of our answers to these questions. Inspired by Kownacki (2002), we later came to call these items transformative moments. They are displayed in Table 1.

\section{Table 1.}

Transformative moments

\begin{tabular}{ll}
\hline $\begin{array}{l}\text { When at our best in the PCD, we are... } \\
\text { Learning about ourselves, others, and } \\
\text { the world }\end{array}$ & Removing barriers to the university \\
\hline $\begin{array}{l}\text { Building relationships with community } \\
\text { members }\end{array}$ & Creating learning opportunities \\
\hline Catalyzing community conversations & Creating critical dialogue \\
\hline Listening to stories & Bridging together different generations \\
\hline Dreaming about what is possible & Enjoying learning \\
\hline Supporting one another & Celebrating life \\
\hline $\begin{array}{l}\text { Assembling resources to promulgate } \\
\text { change }\end{array}$ & $\begin{array}{l}\text { Discovering unknown new knowledge } \\
\text { and wisdom from our members }\end{array}$ \\
\hline $\begin{array}{l}\text { Imagining disparate possibilities, } \\
\text { visions, outcomes, solutions }\end{array}$ & Activating fluid intelligence \\
\hline $\begin{array}{l}\text { Creating collective vision and action } \\
\text { toward that vision }\end{array}$ & $\begin{array}{l}\text { Co-creating experiences between lear- } \\
\text { ners from different generations }\end{array}$ \\
\hline $\begin{array}{l}\text { Writing publications that change or } \\
\text { challenge the field of community } \\
\text { development }\end{array}$ & $\begin{array}{l}\text { Showcasing methods for individuals to } \\
\text { be involved in their communities }\end{array}$ \\
\hline $\begin{array}{l}\text { Pushing the boundaries of community } \\
\text { development theory, methods, and } \\
\text { practice }\end{array}$ & Creating wonderment about life \\
$\begin{array}{l}\text { Inviting others to join our journey } \\
\text { Sor ow }\end{array}$ & Facilitating role transformation \\
\hline
\end{tabular}
Source: own.

The wording, "when at our best," was deliberately chosen to avoid making an audacious claim that our work always embodies these moments as we seek to promulgate the missions of the PCD and OLLI at ASU. Table 1 showcases only some of many possible examples of transformative moments that may emerge in community building and lifelong learning practice. Though not all of these themes will be discussed in detail in this article, they served as anchor points for our exploration of the conceptual affinities between our work in the PCD and OLLI at ASU.

We each prepared a list of ten books or research articles that have personally and deeply shaped our understanding of the community building and/ 
or lifelong learning praxis of the PCD and OLLI at ASU. Many of these are applied with this article and are found in our citations. While reviewing the list of 24 transformative moments (Table 1), we selected key concepts from these pieces of literature to identify common themes in the praxis of both respective organizations. These bridging concepts, and the books and research articles that served as underpinnings for them, eventually came to serve as points of departure for the description of positive pursuits of lifelong learning programs (positive pursuits for short).

\section{POSITIVE PURSUITS}

Our reflective process led us to postulate seven pursuits to re-envision the practice and curriculum of lifelong learning: asset-based thinking; critical reflection; systems thinking; cognitive vibrancy; inclusiveness; creative expression; and, purpose in life. ${ }^{1}$ Pursuant to our conceptual framing above, these pursuits are the crafts of programs that can promote transformative moments in lifelong learning through the infusion of community building principles into lifelong learning practice. The pursuits are not arranged hierarchically. Each pursuit commences with an example of lifelong learning praxis. Then, the pursuit's main tenets are explained. In the summary of each pursuit, we highlight some transformative moments from Table 1 that are connected to each pursuit, and we pose three reflective questions to the reader.

\section{THE PURSUIT OF ASSET-BASED THINKING}

The premise of asset-based thinking is that every individual possesses talents, skills, and experiences from which the whole community can benefit (McKnight, \& Block, 2010). For instance, a community event that draws its strength from the pursuit of asset-based thinking is a potluck: "Potluck is the perfect example of gift giving, community building, hospitality, generosity, all of that in one little word" (McKnight, \& Block, 2010, p. 87). A potluck creates a setting for informal conversations among diverse people bringing a variety of gifts to the table. While sharing a meal, stories converge and assorted foods become one meal, and individuals become a community. When community members gather and are eager to learn from and with others, the power of pursuing asset-based thinking is displayed at its best.

Asset-based thinking as a philosophy has received much attention in asset-based community development. Asset-based thinking encourages researchers and practitioners to help community members to realize and strengthen capacities that already exist within their communities (Kretzmann, \& McKnight, 1993; McKnight, \& Block, 2010). Asset-based community work requires significant effort and intentionality on the part of communities and facilitators to

1 We mirrored our pursuits to reflect Gruidl and Hustedde's (2015) framing of community worker competencies. 
ensure effective public participation and community dialogue (Block, 2009; Haines, 2009). This pursuit relies on asking questions that guide respondents to appreciate what works in their organization or community, and the wellspring of good things in their community.

When community members act together in a common quest to build their capacity to organize, they can reach deep into the hearts of their community stories and elucidate their strengths and talents (Cooperrider, \& Whitney, 2005). Through this process, community members and their organizations learn what works well in their communities and how to strengthen and leverage these capabilities. These collaborative dialogues called appreciative inquiry help stimulate trust and cohesiveness amongst individuals and organizations in the communities. Through appreciative inquiry communities discover, dream, and design their own destinies (Cooperrider, \& Whitney, 2005).

Asset-based thinking is represented in Table 1 by items such as celebrating life, supporting one another, and listening to stories. With the intention to emphasize community building in the context of lifelong learning programming, we pose the following questions:

- Do we create opportunities for lifelong learners to meet outside of the classroom?

- What invitations do we send to our members as we try to set the right tone for lifelong learning through storytelling and sharing of different perspectives?

- How are we showing appreciation and recognition for each individual's gifts?

In summary, asset-based thinking means focusing on a learning community's points of pride rather than on perspectives that are grounded in what is lacking or inadequate.

\section{THE PURSUIT OF CRITICAL REFLECTION}

The second pursuit we propose is critical reflection - a concept described by Freire (2000), Brookfield (1995), and others. Critical reflection heightens one's awareness of underlying assumptions, "the taken-for-granted beliefs about the world and our place within it" (Brookfield, 1995, p. 2). Though intangible, critical reflection assists instructors and students in co-creating learning environments with ample opportunities for profound interactions with each other, the instructors, and the community beyond the classroom. In this scenario, learners adopt a spirit of collaboration that embodies respect for the lived experience and knowledge of all learners and is open to challenging the assumptions of students and instructors alike. In a similar vein, those in higher learning have been encouraged to challenge the contextual factors that can often mire university-community partnerships. (Archer-Kuhn, \& Grant, 2014).

In moving toward such a process, the instructor embraces the notion that he or she is not the only voice of authority in the classroom. To be sure, life- 
long learning opportunities cannot avoid the dynamics of privilege and power that are found in all teacher-student configurations. At the same time, the process of critical reflection, which uncovers power dynamics (Freire, 2000), is an important discipline and practice for moving the learning experience more toward a co-creative process. Critical reflection is grounded in critical thinking, which is "a way of approaching ideas that aims to understand core, underlying truths, not simply that superficial truth that may be most obviously visible" (hooks, 2010, p. 9).

We have come to appreciate the idea of reciprocity and the importance of honoring various kinds of expertise in our own projects (see, for example, Pstross, Talmage, \& Knopf, 2014). Our work mirrors Stewart and Alrutz's (2012) premise that "transformative and reciprocal relationships prove essential to pedagogies of engagement" (p. 44). Yet the fields of lifelong learning and community building appear dominated by the viewpoints of the facilitator or teacher (hooks, 2010). The wisdom and transformative power behind becoming teachers among teachers and students among students (Freire, 2000) offer significant insight for how to structure lifelong learning offerings. Glover and Silka (2013) highlight that in university-community partnerships the question of "who initiates engaged campus-community partnerships" (p. 38) and the power dynamics wrapped within this question goes far too often neglected. Indeed, learning environments that neglect to address power differences are likely to run the risk of ignoring non-dominant practices and knowledge in the way that dominant structures have done (McMichael, 2012).

Referring back to Table 1, the pursuit of critical reflection is represented in the creation of a critical dialogue, through the discovery of unknown new knowledge and wisdom from our members, and in role transformations that are grounded in a deep personal and collective reflection about a person's place in a community. We conclude the following questions to encourage critical reflection as a pursuit:

- How might we prepare instructors in our class offerings to adopt critical reflection in their teaching practices?

- What steps will we take in order to encourage our students to be critically reflective?

- What steps can be taken to equalize access to expertise by students and instructors in our classrooms?

All learners are important in the co-creation of learning experiences. Reflection allows for expertise to be shared and multiplied.

\section{THE PURSUIT OF SYSTEMS THINKING}

The third pursuit is to deliver lifelong learning offerings that are rife with systems thinking. Systems thinking refers to the capacity to interpret the dynamics of a particular phenomenon in the context of a larger whole (von Bertalanffy, 1968). The power of systems thinking becomes activated when an instructor demonstrates relevance between the topic taught and other aspects 
of social and community life. For example, a class on the nature in the American Northeast may incorporate discussions of human activities that either support or delimit the bare existence of certain species. It may also pose questions on how each learner may project these lessons into their own lives (e.g., environmentally driven actions such as recycling).

The imperative to employ systems thinking to address many of life's challenges and community development issues has been popularized, among others, by Jay Forrester (1971), Mary Emery and Cornelia Flora (2006), and Peter Senge (2006). In Senge's view, humans are intertwined in social systems (i.e., organizations and communities), which operate in patterns of influential and interactive feedback loops. Systems thinking concerns the relationship between specific situations in a person's life and the dynamics of the wholes of complex systems not just individual parts (Senge, Scharmer, Jaworski, \& Flowers, 2005; Senge, 2006). "Neither exists without the other. The whole exists through continually manifesting in the parts, and the parts exist as embodiments of the whole" (Senge et al., 2005, pp. 9-10). From the standpoint of our positive pursuits, the goal is to encourage lifelong learners to break any myopic and rote interpretations of phenomena, and build more complex and dynamic interpretations of cause and effect. In other words, the focus becomes less on dispensing facts and more on studying interactive dynamics. New forms of learning about the dynamics of interactive systems replace old habits of rote knowledge acquisition, and the role of community systems. As a powerful by-product, the individual interprets his or her role in the world in the context of higher order community systems. Thus, the learner builds higher levels of self-efficacy in being able to more effectively navigate the community systems that influence him or her (Freire, 2000).

Depth and awareness of surrounding systems, which Senge and colleagues (2005) term presence, is needed to break rote learning - where one's pre-existing mental models keep re-enacting old habits of knowledge acquisition. Presence is described as "deep listening," and "consciously participating in a larger field for change" (Senge et al., 2005, p. 16). Presence expands cognition, awareness of how the environment influences individuals, and how individuals influence the environment; thus, it can generate greater self-efficacy and collective efficacy for individuals and communities. Presencing, which involves learning as the future emerges, can also be a complementary practice for community building, such that community members come together around systematic discussions of social issues (Senge et al., 2005).

In Table 1, systems thinking is demonstrated in items imagining disparate possibilities, visions, outcomes, solutions, and showcasing methods for individuals to be involved in current affairs in their communities. Additionally, we pose these questions:

- What guidelines do we give to our instructors so that they present topics holistically?

- How willing are we to pursue depth and awareness in our learning experiences? 
- How are we inviting learners to share their expertise with life's various systems?

In summary, the pursuit of systems thinking allows lifelong learning programs to provide a mindful and holistic rather than pieced-apart understanding of class topics.

\section{THE PURSUIT OF COGNITIVE VIBRANCY}

Cognitive vibrancy is the fourth pursuit that we identified. It refers to the active and creative stimulation of individual minds during classroom activities. These kinds of stimulation often do not occur solitarily, but in supportive social environments (Hafford-Letchfield, 2010). Going beyond the adage "keep your mind active or you'll lose it", cognitive vibrancy is exemplified in classroom settings where the instructors challenge learners to come up with creative solutions to world problems. In the process, students have a chance to discuss and build upon each other's responses. Thus, the ideas of other people force learners to respond and think as their own points of views are being contested.

Throughout all stages of life, creativity is important to community and individual and wellbeing. Kay (2000) discussed the positive impact of arts on communities. On an individual level, challenging our brains through creative exercises and encouraging creativity, in general, helps improve brain plasticity and/or neuroplasticity (Cohen, 2006; 2009). Art activities appear to be particularly salient in impacting plasticity and decreasing the risk of dementia-type disorders (Cohen, 2006; Verghese et al., 2003). Cohen (2009) writes, "new findings on brain plasticity have catalyzed the exploding attention to brain fitness, which is as important now to most older persons as physical fitness" (p. 426). Cognitive vibrancy is only one indicator of psychological health.

Aaron Antonovsky (1979) constructed his systematic theory of salutogenesis (literally meaning healthy origin). The theory reflects a positive psychological focus on the antecedents of health and wellbeing. Healthy psychological living is based on the depth of an individual and community's level of sense of coherence, comprehensibility, manageability, and meaningfulness (for more, see Antonovsky, 1987). In this attempt, lifelong learning programs should strive to provide creative and intellectually stimulating activities for their learners.

The pursuit of cognitive vibrancy directly pertains to the following items in Table 1: imagining disparate possibilities, visions, outcomes, solutions, and discovering unknown new knowledge and wisdom from our members. The questions below can guide us in following this pursuit:

- How challenging or in-depth are the questions asked in classes and do they allow disparate points of views to emerge from different learners?

- What activities do we incorporate into our curriculum to enhance creative expression?

- Are we inviting our students to reflect on meaningful past experiences in their lives and to share these experiences with others? 
Through the pursuit of cognitive vibrancy, we are creating opportunities for our learners to remain mentally acute and to engage in a discussion with others.

\section{THE PURSUIT OF INCLUSIVENESS}

The fifth pursuit is inclusiveness. The presence of diverse assets is not sufficient enough alone to facilitate the inclusion and leveraging of those assets. Therefore, it matters whom we welcome to our communities of learning. Many start with diversity, but respect for diversity requires inclusion and equity (Ochocka, Moorlag, \& Janzen, 2010). While lifelong learning programs such as OLLI at ASU focus especially on the provision of educational opportunities to older adults, the pursuit of inclusiveness guides us in creating educational spaces that welcome different groups. For example, events or activities, which are open to other generations, can reflect inclusiveness. Learning with those who have different social locations can enrich lives.

Women, minorities, those with disabilities, the impoverished, and many other marginalized groups have been excluded from both the structuring and benefits of countless community building projects (Sen, 1999). A view of the future that includes an empowered and educated populace must take these groups into consideration from the beginning, not add them to an already constructed institution (Nussbaum, 2011). Congruently, Mulligan, Scanlon, and Welch (2008) write, "social inclusion can also be used as a critique of social practices and structures that constantly recreate division and 'disadvantage'" (p. 54). Fittingly, lifelong learning has been deemed a community tool for overcoming social exclusion, facilitating social inclusion and cohesion, reducing poverty, and promoting active citizenship (Frazer, 2005; Taylor, 2008; Thompson, 2002). Downie and Elrick (2000) wrote of active citizenship, lifelong learning, and social inclusion as threads to be woven in our community work. In the same light, Taylor (2008) has called for "higher education institutions to become inclusive and democratic spaces where critical analysis of social issues is fostered" (p. 358).

Among other reasons, inclusiveness in the structuring of lifelong learning is important because it is where the framing of topics, issues, problems, and solutions begins. Inclusive framing allows people to name their own questions, problematize the world through their lens, and seek answers that speak to their values (Lewis, 2012; Smith, 2012). Too often, those who suffer from poverty or are otherwise marginalized are made out to be the problem to be solved. It is rarely the powerful or wealthy whose circumstances are said to be a challenge or in need of combating (Rist, 2014).

Smith (2012) and Hooks (2010) analyzed the complex relationship between dominant and marginalized groups. They noted that it is simply not enough in community building to say, "We extended the invitation, we've done all we can," and then expect inclusive spaces to emerge as a result of your good inten- 
tions. So too, does an inclusive program of lifelong learning require uncommon efforts and an examination of power and other barriers. An invitation to come and be like us is not inclusive; it is assimilative.

Inclusion, therefore, requires a honoring of diversity characterized by the desire to unleash the asset of difference rather than to manage it. Inclusion that requires significant assimilation of actions or values too often results in the re-marginalization of communities who have historically been left out of educational and community building opportunities (McIntosh, 1983). These spaces may have all the appearances of efficiency or harmony, but rarely result in something long lasting or healthy. Inclusiveness requires respect for alternative ways of being, knowing, learning, and teaching (McIntosh, 1983). The pursuit of inclusiveness complements the practices of humility, vulnerability, and reflexivity discussed in the pursuit of critical reflection.

In numerous ways, the pursuit of inclusiveness echoes elements of Table 1: removing barriers to the university, co-creating experiences between learners from different generations, imagining disparate possibilities, visions, outcomes, solutions, and learning about ourselves, others, and the world. The following questions help explore this pursuit:

- Who is not in our classrooms currently?

- What messages are engrained in the invitations we send out?

- In the classroom setting, are we - as instructors and students - willing to put ourselves in positions of vulnerability as we embrace diversity?

The pursuit of inclusiveness directs us to open educational opportunities to all and to welcome those whose social location may be different from our own or our friends.

\section{THE PURSUIT OF CREATIVE EXPRESSION}

The pursuit of creative expression challenges lifelong learning programmers to create opportunities for learners that allow them to immerse themselves in artistic and playful interactions with each other. These activities such as respectful joking, dancing, and singing, foster positive attitudes to other community members and to learning in general. Transformations through creative expression acquire a literal meaning when somebody role-plays a different character in a class. This can be particularly powerful for a person engaging a form of creativity that has previously felt out of reach or out of character (Ledwith, \& Springett, 2010). This shakes up the etiquette of the situation and serves as an invite for others to join as a respected participant in the community of learners.

The pursuit of creative expression involves an intentional building of learning opportunities through performance, role-playing, and art. This unlocks unexpected learning opportunities, as people leave stereotypes behind and engage in improvised interactions with their fellow students. In addition, creative expression allows the lines of outsider and insider to the community 
to become blurred; the gifts of the group are allowed to dialogically emerge as participation deepens (Westoby, \& Dowling, 2013). Drawing on the traditions set forth by Freire and Gramsci, Purcell (2012) summarizes the role of adult educators and community development practitioners who educate as, "to facilitate the challenging of the notion of 'common sense' and the everyday acceptance of structures, system and hierarchies as being both right and inevitable" (p. 271). Similarly, Wheatley and Frieze (2011) have argued that creative expression is often carried in by playfulness that breaks through the established systems of rules within a particular social context. Furthermore, Hoggan, Simpson, and Stuckey (2009) and their colleagues have shown how the reading and creative writing of stories, photography, making of collages, music production, the practice of intuition, and other forms of creative expression enable learners to view their life situations differently and to revise their opinions and beliefs.

Creative expression directly pertains to the following items from Table 1 : dreaming about what is possible, enjoying learning, activating fluid intelligence, and role transformation. We pose the following reflective questions:

- How can creative expression be cultivated among our communities of our learners?

- What roles are we allowed to play and perform in the classrooms?

- As we interact with one another, what are we learning and how do we use what we are learning beyond the classroom?

The pursuit of creative expression allows communities of learners to adapt new perspectives as they reflect on their life situation and their place in the community.

\section{THE PURSUIT OF PURPOSE IN LIFE}

The last pursuit that we highlight is the pursuit of purpose in life. This pursuit challenges lifelong learning programs to offer opportunities for engaging learners in activities through which they can give back to the community. An example of this is when one adapts a new role in their community in a volunteer position as an organizer or leader; in that scenario, both the volunteer and the community benefit.

We describe the pursuit for the meaning of life as a desire for thriving. Thriving is inherent to individual intellectual and leadership growth as well as growing of relationships and community building. The etymology of the word to thrive points to meanings such a "grasp to oneself" or to "flourish" (Online Etymology Dictionary, n.d.). A key notion is that the relationship between a person and their community is not unidirectional. Developmental psychologist Richard Lerner (2004) argues thriving occurs when both an individual and that individual's community grow together. While Lerner focuses on the civic engagement of youth, his notions are applicable to all age groups. Lerner's understanding is that thriving is inseparable from a per- 
son's involvement in the community and is connected to moral development as well (Lerner, 2004).

The pursuit of life's purpose is discussed in Frankl's (2006) book Man's Search for Meaning. Frankl (2006) notes the importance of self-worth and life purpose in serving others that in turn helps a person overcome complex life circumstances. The meaning of life is contextual and subjective: "[It] differs from man to man, from day to day and from hour to hour. What matters, therefore, is not the meaning of life in general but rather the specific meaning of a person's life at a given moment" (p. 108).

Frankl (2006) emphasizes individuals' abilities to rise above the everyday: "self-actualization is possible only as a side-effect of self-transcendence" ( $p$. 109). Frankl's work suggests that self-transcendence means giving preference to another person. Through activities, such as volunteering and generally serving others, the meaning of life unfolds despite the suffering that a person may encounter. This is where Frankl's work meets Lars Tornstam's (2011) theory of gerotranscendence. Tornstam claims that individuals' conceptions of the world and their social and personal relationships change, as they get older. With the intention to leave a legacy, they often bring forth and use their gifts in the service to others.

The writings of Frankl, Lerner, and Tornstam add an important dimension to lifelong learning programming, which emphasizes that serving others nurtures satisfaction, self-worth, and meaning. These notions link to the following items in Table 1: role transformation, celebrating life, supporting one another, and inviting others to join our journey. The following reflective questions may help us think about that the pursuit of purpose in life means to our programming:

- Do our classes allow for reflection on what it means to leave a legacy?

- What volunteer opportunities do we promote in our organizations and programs?

- What helps us establish an atmosphere of sharing and serving inside and outside of our communities?

The pursuit of purpose in life challenges lifelong learning programs to consider ways how to enable members to leave a legacy. To conclude, we now turn to how the seven pursuits enlighten our opening question about the relationship between community building and lifelong learning.

\section{WRAPPING UP POSITIVE PURSUITS}

While reflecting on our dual experiences from the PCD and OLLI at ASU, we formulated seven pursuits of community building: asset-based thinking; critical reflection; systems thinking; cognitive vibrancy, inclusiveness; creative expression; and, purpose in life. Each one challenges educators and lifelong learning programmers to consider the benefits of building a community in lifelong learning practice. In resonance with Gruidl and Hustedde (2003, 2015), we see the seven pursuits as crafts of lifelong learning programming. Building on 
Kownacki (2002), we claim that when done well, the pursuits can spur positive transformations in lifelong learners' lives and within their learning communities as a whole. The transformations are exemplified in a heightened sense of community, connection, and empowerment that motivate lifelong learners to reflect on their roles in their own communities as learners, citizens, and leaders.

The pursuits are the inspiration for and an expression of praxis. They are moving targets; they are not automatic and for this reason they must constantly be renewed through lifelong learning praxis (see Freire, 2000). They help educators create opportunities for learners to experience transformative moments. The relationship between pursuits and transformative moments is bi-directional and co-constitutive. The pursuits further provoke learners to rethink their roles in communities. While the implementation of the seven pursuits may manifest differently from one lifelong learning program to another, the intentionality provides an avenue for the creation of transformative moments.

\section{A METAPHOR OF BREAD}

In order to illustrate how transformative moments occur and why they are important, we use the metaphor of bread making. Different ingredients can create different kinds of bread, however, two are essential: grain (usually flour) and water. Typically, these are then baked. The process is further influenced by factors such as the amount of heat or dimensions of the oven. Through an irreversible process of baking, ingredients in bread become transformed into a new product, and the community that serves and consumes the bread is also contextually transformed.

More notably, it is at the moment that the bread is shared with the community that the bread gains an importance beyond nourishment. As religious rituals in various cultural contexts around the world show, bread making often has a sacred meaning to the whole community with examples including Passover celebration, Holy Eucharist, or the Sikh Langar tradition. In our metaphor, community building and lifelong learning represent the essential ingredients: flour and water. We claim that the seven pursuits enable practitioners to blend community building into lifelong learning programs and in the process usher in moments of transformation that result in nourishing bread.

Why is all of this important? Building on the metaphor, we suggest that bread is good for the body and the soul. It can simultaneously feed people and build community as people "break bread." During bread making original ingredients transpose and modulate in synergy into a brand new product. Similarly, when students enter a lifelong learning program that has these pursuits in mind and intentionally implements the pursuits into programming, transformations may happen at both the individual level and at the community level. 


\section{CONCLUSION}

In this article, we reflected on ways how community building enhances lifelong learning practice, so that they may lead to learning experiences that are more optimally engaging for learners. We have proposed that our seven pursuits enlighten the relationship between community building and lifelong learning and can create a context for transformative moments to transpire. As in bread making, there are a vast number of recipes that can lead to a final product, but each one requires basic ingredients, an oven, and a patient bread maker, who is intentional about how these ingredients blend together.

In line with the modality of this article, we conclude by posing the following questions for the reader to ponder:

- What positive transformations have you seen among the members of your educational programs?

- What positive transformations for individuals and communities would you like to see?

- How can you be intentional at stimulating positive transformations in your own programs that promote lifelong learning?

We invite the reader to join us in seeking answers to these important questions through their work in their own communities.

\section{REFERENCES}

[1] Antonovsky, A. (1979). Health, stress, and coping. San Francisco: Jossey-Bass.

[2] Antonovsky, A. (1987). Unraveling the mystery of health: How people manage stress and stay well. San Francisco: Jossey-Bass.

[3] Archer-Kuhn, B., \& Grant, J. (2014). Challenging contextual factors in university-community partnerships. Journal of Community Engagement and Scholarship, 7 (2), 40-49.

[4] Bertalanffy, L. V. (1968). General system theory: Foundations, development, applications. New York: Braziller.

[5] Bhattacharyya, J. (1995). Solidarity and agency: Rethinking community development. Human Organization, 54 (1), 60-69.

[6] Block, P. (2009). Community: The structure of belonging. San Francisco: Berret-Koehler.

[7] Brookfield, S. D. (1995). Becoming a critically reflective teacher. San Francisco: Jossey-Bass.

[8] Cohen, G. (2006). Research on creativity and aging: The positive impact of the arts on health and illness. Generations, 30 (1), 7-15.

[9] Cohen, G. D. (2009). Historical lessons to watch your assumptions about aging: Relevance to the role of International Psychogeriatrics. International Psychogeriatrics, 21 (03), 425-429.

[10] Cooperrider, D. \& Whitney, D. D. (2005). Appreciative inquiry: A positive revolution in change. San Francisco: Berrett-Koehler.

[11] Downie, A., \& Elrick, D. (2000). Weaving the threads: Community development and organizing around the environment - a Scottish perspective. Community Development Journal, 35 (3), 245-254.

[12] Emery, M., \& Flora, C. (2006). Spiraling-up: Mapping community transformation with community capitals framework. Community Development, 37 (1), 19-35.

[13] Fehren, O. (2010). Who organises the community? The university as an intermediary actor. Gateways: International Journal of Community Research and Engagement, 3, 104-119.

[14] Forrester, J. W. (1971). Counterintuitive behavior of social systems. Theory and Decision, 2 (2), 109-140. 
[15] Frankl, V. E. (2006). Man's search for meaning. Boston, Beacon.

[16] Frazer, H. (2005). Setting the scene Europe-wide: The challenge of poverty and social exclusion. Community Development Journal, 40 (4), 371-384.

[17] Freire, P. (2000). Pedagogy of the oppressed. New York: Continuum.

[18] Glover, R. W., \& Silka, L. (2013). Choice, power and perspective: The neglected question of who initiates engaged campus-community partnerships. Gateways: International Journal of Community Research and Engagement, 6 (1), 38-56.

[19] Gruidl, J., \& Hustedde, R. (2015). Towards a robust democracy: The core competencies critical to community developers. Community Development, 46 (3), 279-293.

[20] Gruidl, J., \& Hustedde, R. (2003). Key practices in creating a learning community. In: N. Walzer (Ed.) The American Midwest: Managing change in rural transition (pp. 246-264). Oxon: Routledge.

[21] Hafford-Letchfield, T. (2009). The age of opportunity? Revisiting assumptions about the life-long learning opportunities of older people using social care services. British Journal of Social Work, 40 (2), 496-512.

[22] Haines, A. (2009). Asset-based community development. In: R. Phillips, \& R. H. Pittman, (Eds.) An introduction to community development (pp. 38-48). New York: Routledge.

[23] Hoggan, C., Simpson, S., \& Stuckey, H. (Eds.). (2009). Creative expression in transformative learning: Tools and techniques for educators of adults. Malabar: Krieger.

[24] hooks, b. (2010). Teaching critical thinking: practical wisdom. New York: Routledge.

[25] Horn, J. L., \& Cattell, R. B. (1967). Age differences in fluid and crystallized intelligence. Acta Psychologica, 26, 107-129.

[26] Jarvis, P. (2004). Adult education and lifelong learning: Theory and practice (3rd ed.). London: Routledge.

[27] Kay, A. (2000). Art and community development: The role the arts have in regenerating communities. Community Development Journal, 35 (4), 414-424.

[28] Kownacki, M. L. (2002). The nonviolent moment: Spirituality for the 21st century. Erie: Pax Christi.

[29] Kretzmann, J. P., \& McKnight, J. L. (1993). Building communities from the inside out: A path toward finding and mobilizing a community's assets. Chicago: ACTA.

[30] Lau, M. A., Bishop, S. R., Segal, Z. V., Buis, T., Anderson, N. D., Carlson, L., \& Devins, G. (2006). The Toronto mindfulness scale: Development and validation. Journal of Clinical Psychology, 62 (12), 1445-1467.

[31] Ledwith, M., \& Springett, J. (2010). Participatory practice: Community-based action for transformative change. Chicago: Policy Press.

[32] Lerner, R. M., (2004). Liberty: Thriving and civic engagement among America's youth. Thousand Oaks: Sage.

[33] Lewis, L. (2012). The capabilities approach, adult community learning and mental health. Community Development Journal, 47 (4), 522-537.

[34] McIntosh, P. (1983). Interactive phases of curricular re-vision: A feminist perspective. Working paper No. 124. Wellesley, Wellesley Centers for Women, Wellesley College.

[35] McKnight, J., \& Block, P. (2010). The abundant community: Awakening the power of families and neighborhoods. San Francisco: Berrett-Koehler.

[36] McMichael, P. (2012). Development and social change: A global perspective (5th ed.). Thousand Oaks, Sage.

[37] Mezirow, J. (1996) Contemporary paradigms of learning. Adult Education Quarterly, 46 (3), 158-172.

[38] Moreland, R., \& Lovett, T. (1997). Lifelong learning and community development. International Journal of Lifelong Education, 16 (3), 201-216.

[39] Mulligan, M., Scanlon, C., \& Welch, N. (2008). Renegotiating community life: Arts, agency, inclusion and wellbeing. Gateways: International Journal of Community Research and Engagement, 1, 48-72.

[40] Nussbaum, M. (2011). Creating capabilities: The human development approach. Cambridge: Belknap.

[41] Ochocka, J., Moorlag, E., \& Janzen, R. (2010). A framework for entry: PAR values and engagement strategies in community research. Gateways: International Journal of Community Research and Engagement, 3, 1-19. 
[42] Online Etymology Dictionary. (2014). Thrive. Retrieved from http://www.etymonline.com/ index.php?term=thrive.

[43] Osher Lifelong Learning Institute at ASU. (n.d.). Retrieved May 24, 2017, from http://lifelonglearning.asu.edu.

[44] Partnership for Community Development. (n.d.). Retrieved May 24, 2017, from http:/ /scrd. asu.edu/pcd.

[45] Pstross, M., Talmage, C. A., \& Knopf, R. C. (2014). A story about storytelling: Enhancement of community participation through catalytic storytelling. Community Development, 45 (5), 525-538.

[46] Purcell, R. (2012). Community development and everyday life. Community Development Journal, 47 (2), 266-281.

[47] Rist, G. (2014). The history of development: From western origins to global faith (4th ed.). New York: Zed Books.

[48] Sanders, I. T. (1966). The community: An introduction to a social system (2nd ed.). New York: Ronald.

[49] Schugurensky, D. (2007). The learning society in Canada and the US. In: M. Kuhn (Ed.), New society models for a new millennium. The learning society in Europe and beyond (pp. 295-334). New York: Peter Lang.

[50] Sen, A. (2009). The idea of justice. Cambridge: Belknap.

[51] Senge, P. M. (2006). The fifth discipline: The art and practice of the learning organization. New York: Random House.

[52] Senge, P. M., Scharmer, C. O., Jaworski, J., \& Flowers, B. S. (2005). Presence: An exploration of profound change in people, organizations, and society. New York: Random House.

[53] Shaw, M., \& Crowther, J. (2014). Adult education, community development and democracy: Renegotiating the terms of engagement. Community Development Journal, 49 (3), 390-406.

[54] Stewart, T., \& Alrutz, M. (2012). Meaningful relationships: Cruxes of university-community partnerships for sustainable and happy engagement. Journal of Community Engagement and Scholarship, 5 (1), 44-55.

[55] Taylor, E. W. (2007). An update of transformative learning theory: A critical review of the empirical research (1999-2005), International Journal of Lifelong Education, 26 (2), 173-191.

[56] Taylor, P. (2008). Where crocodiles find their power: learning and teaching participation for community development. Community Development Journal, 43 (3), 358-370.

[57] Thompson, J. (2002). Bread and Roses: Arts, Culture and Lifelong Learning. Leicester National Institute of Adult Continuing Education, Renaissance House.

[58] Tornstam, L., (2011). Maturing into gerotranscendence. Journal of Transpersonal Psychology, 43 (2), 166-180,

[59] Verghese, J., Lipton, R. B., Katz, M. J., Hall, C. B., Derby, C. A., Kuslansky, G., \& Buschke, H. (2003). Leisure activities and the risk of dementia in the elderly. New England Journal of Medicine, 348 (25), 2508-2516.

[60] Westoby, P., \& Dowling, G. (2013). Theory and practice of dialogical community development: International perspectives. New York: Routledge.

[61] Wheatley, M., \& Frieze, D. (2011). Walk out walk on: A learning journey into communities daring to live the future now. San Francisco: Berrett-Koehler. 